\title{
短波長赤外領域スペクトル情報を用いた人肌領域抽出に関する研究
}

\section{Studies on the extraction of human skin using spectral information in shortwave infrared band}

\author{
枝長＼cjkstart孝幸*・宇都 有昭*・小杉＼cjkstart幸夫* \\ Takayuki EDANAGA, Kuniaki UTO and Yukio KOSUGI
}

\begin{abstract}
Recently, there were various disasters such as Katrina flood, seismic wave in Sumatra, great earthquake in several countries. In these disasters, it has become one of the most important rescue activities to detect quickly the victims. If automatic detection of these victims in vast disaster fields is feasible, searching efficiency will be improved spectacularly in comparison with traditional visual search from aircrafts. In this paper, we propose Normalized Difference Human Index (NDHI) in order to extract human images out of various background objects efficiently. For the NDHI, we examine spectral characteristics of the human skin in short wave infrared band, and chose the best wavelengths for its calculation. For marine peril or water disasters, we have conducted experiments with human extraction in and out of the mud water using NDHI. In order to extract objects in the mud water, it is necessary to calculate the threshold operation on the reflectance of $1070 \mathrm{~nm}$ wavelength as preprocessing of NDHI. In addition, we examined allowable water depth to extract objects for each transparency (intermediate-water, 40 , $20,10 \mathrm{~cm})$. Finally, comparable studies with the conventional thermography measurements were also carried out.
\end{abstract}

\section{1.はじめに}

リモートセンシング技術の発達に伴い，土地利用分 布の分類等にスペクトル情報が用いられており,植生, 鉱物などの自然の地表物の定量的評価のために， NDVI (Normalized Difference Vegetation Index) をはじめとするさまざまな指標が提案されてきてい る。我々もスペクトル情報の応用研究の一環として, ヒトを対象とした人肌抽出指標の開発を試みている。 ヒトへの適用が可能になれば，この指標は大規模な自 然災害が発生した際, 被災者の救出活動において有用 となるであろう。世界各国での大震災，スマトラ沖の 津波,メキシコ湾で発生したカトリー十等にみられる ように, 災害発生時の人命確保は最優先課題である。

*東京工業大学大学院総合理工学研究科

Interdisciplinary Graduate School of Science and Engineering, Tokyo Institute of Technology

２226-8502 横浜市緑区長津田町4259

東工大すずかけ台キャンパス G2-16

「写真測量とリモートセンシング」VOL. 46，NO. 2， 2007
これまでは, へリコプターなどからの目視による被災 者認識が行われてきたが, 被災地域の広域な画像情報 からヒトの所在を迅速に探知できるようになれば，被 災者の救助活動に大変役立つと考之られる。さまざま な背景からヒ卜を抽出する上で，ポイントとなるのが 人肌である。人肌については，環境変化によるUVの 影響調査のほか, 診断, 治療等の医療的な観点から, UV から NIRにかけての波長域における人肌特有の 光学特性が調査されている(Bashkatov, 2005)。また, 皮䖉のスペクトルを利用した個人特定の研究 (Pan, 2003）や，ヒト識別では皮下のへモグロビンの可視領 域でのスペクトル吸収特性を利用した研究も行われて いる (Angelopoulou, 1999)。本研究では, 光学特性が 解明されつつある短波長赤外領域に着目し，その波長 帯域の七トと背景物の反射スペクトルの違いに基づ き，ヒトをさまざまな背景物（アスファルト，コンク リート，植物，土砂など）から抽出する指標 NDHI (Normalized Difference Human Index) を提案する。 人肌抽出による要救助者の捜索は, 肌が多く露出して いる海水浴, マリンスポーツ等での水難事故, 及び津 波や洪水災害後に利用することで有用性を発揮すると 
考えられる。このような場合，実際には水が不透明に 濁っていることが多い。そこで，NDHIを利用した泥 水の内外の人肌抽出について検証実験を行った。また, NDHI の有用性を調べるために，赤外線カメラを用い た体温感知によるヒ卜認識との比較を行った。

\section{2. 実験装置}

実験では波長ごとのスペクトルの強度の詳細を調べ る必要があるため，ハイパースペクトルセンサを使用 した。ハイパースペクトルセンサはプリズムと回折格 子から構成される PGP 分光部 (Specim 社製 Imspector-N17) とCCD 部（Sensors Unlimited 社製 SU320M-1.7RT) から構成されている。このセンサの 測定波長帯域は短波長赤外の前半領域の $950 \mathrm{~nm}$ から $1700 \mathrm{~nm}$ であり, CCDのピクセル数は空間軸方向に 240 ピクセル，波長軸方向に 320 ピクセル，記録速度は 最高で 1 秒当たり 30 フレームのラインセンサである。 デー夕取得時には, 白色板の DN 值 (Digital Number) 及び暗電流值によるデー夕補正を行った。実験装置は 屋外と室内の測定系の 2 種類に分けた。屋外の測定系 では, 日本精工侏製のメガトルクモー夕 YSB2020の上 にセンサを固定し，このモータを回転させ，センサの 水平方向に配置された測定対象物に対してラインス キャンを行った。室内の測定系では, IAI (侏)製の直動ア クチュエータ RCS-SM-100に固定したセンサを水平 移動させることで垂直下向きの測定対象物に対してラ インスキャンを行った。室内の測定系の照明条件とし ては, データの精度向上のため外来光を遮断し, セン サと一体駆動される $500 \mathrm{~W}$ のハロゲンランプ 2 個を用 いた。照明の照度は白色板補正位置で約 $19000 \mathrm{Lx}$ で あった。

\section{3．人肌抽出指標 NDHI}

\section{1 人肌抽出の計算手法}

実際に要救助者の捜索に人肌抽出指標を利用する場 合, 指標は広域な画像データに対して即時に演算が可 能な計算式であることが望ましい。さらに今後, 観測 の高速化を実現するため, 機械的なラインスキャンを 用いず 2 次元の空間情報を取得可能な装置の開発を考 慮すると,できるだけ少ないチャンネル数の利用が有 用であると考えられる。そこで植生指標 NDVIのよう
な 2 波長間の反射率のギャップを利用した指標につい て考之る。植生指標 NDVIは, 植物の緑葉が青領域と 赤領域の波長を吸収し, 近赤外線領域の波長を強く反 射する特性を利用したものである（Ustin，2004）。 NDVIは，近赤外波長 (IR) と赤波長（R）の值を用い て，正規化された式(1)で算出されている。

$$
N D V I=\frac{I R-R}{I R+R}
$$

人肌のスペクトルは，オキシへモグロビンの影響に より $410 \mathrm{~nm}, 540 \mathrm{~nm}, 575 \mathrm{~nm}$, 水分の影響により $970 \mathrm{~nm}$, $1430 \mathrm{~nm}, 1925 \mathrm{~nm}$, 脂質の影響により $1710 \mathrm{~nm}$ から 1780 $\mathrm{nm}$ 間，また水分及び脂質の影響により $1200 \mathrm{~nm}$ の波長 域においてそれぞれ吸収特性がある（Bashkatov， 2005)。特にオキシへモグロビンの影響による $410 \mathrm{~nm}$, 水分の影響による $1430 \mathrm{~nm}, 1925 \mathrm{~nm}$ に大きなスペクト ル吸収特性を持つ。これに対し, $1100 \mathrm{~nm}$ 付近では最も 両者の吸収の影響が少なく，基準とするのに適した波 長である。オキシへモグロビンはヒトの真皮中の血管 に多く存在するため, 人肌を抽出するのに大きな手が かりになると考えられる。しかし，この $410 \mathrm{~nm}$ 付近の 短い波長は大気散乱の影響を受け易いため反射強度が 安定しない。また, $1100 \mathrm{~nm}$ を基準と考えた場合, 可視・ 近赤外領域と短波長赤外領域を同時に測定するために 2 種類の CCD 部が必要になり, 光学系の構成が複雑 になる。そこで, 我々は 2 波長間の反射率のギャップ が大きく, 最も近接する波長带である短波長赤外領域 の波長に着目し，スペクトル吸収が小さく高い反射率 を持つ $1100 \mathrm{~nm}$ 付近及び，水分による吸収が大きい $1430 \mathrm{~nm}$ 付近の波長を用いた指標を提案する。人肌抽 出指標は, $1100 \mathrm{~nm}$ 付近の反射率を $\mathrm{R} 1,1430 \mathrm{~nm}$ 付近の 反射率を $\mathrm{R} 2$ と，次式(2)から算出する。

$$
N D H I=\frac{R 1-R 2}{R 1+R 2}
$$

以下，式(2)における人肌抽出に適切な $\mathrm{R} 1$ と 2 を調 べるとともに，指標の検証実験を行った。

\section{2 人肌抽出指標に適切な波長の選択}

人肌抽出に適切な波長を調べるため，八イパースペ クトルセンサを使用して屋外において七トと背景を含 む範囲を測定した。測定した背景には，建物のコンク リート壁面, アスファルト道路, 芝生などの植生が含 まれていた (Figure 1)。得られた人肌とそれぞれの背 景物の反射スペクトル特性を Figure 2 に示す。NDHI 


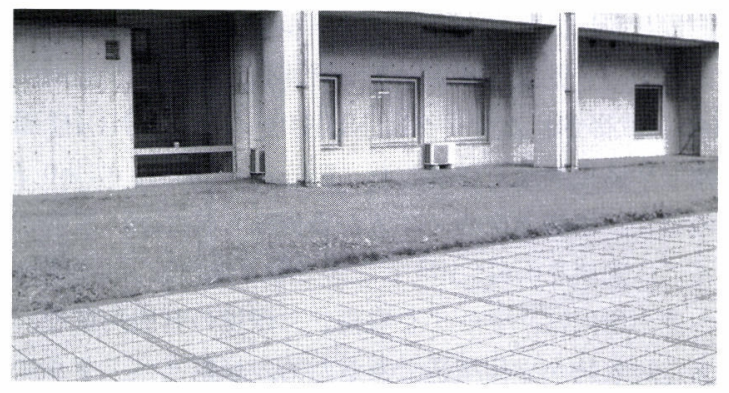

Figure 1 Background objects (concrete wall, asphalt road and vegetation).

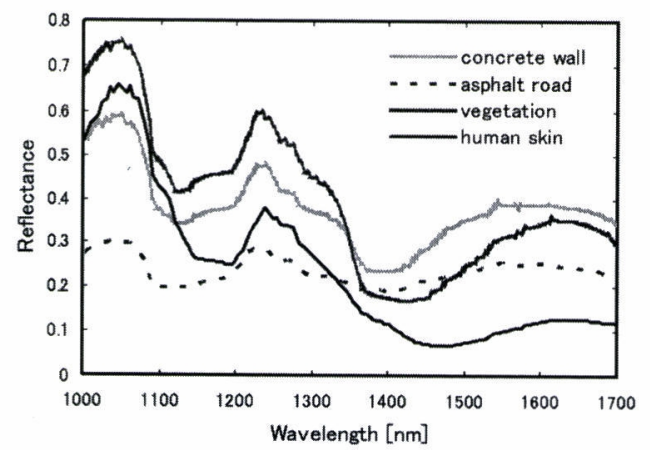

Figure 2 Hyperspectral reflectance profiles of human skin, concrete wall, asphalt road and vegetation.

に適切な波長を見つけるために， R1は1000nmから $1200 \mathrm{~nm}, \mathrm{R} 2$ は $1400 \mathrm{~nm}$ から $1600 \mathrm{~nm}$ の範囲で人肌とそ れぞれの背景物との NDHI 值の差を調べた。この結果 を Figure $3(\mathrm{a})(\mathrm{b})(\mathrm{c})$ に示す。この NDHI の差が大きい ほど, 背景から人肌の抽出力が上がると考えられる。 まず，人肌とコンクリート壁面では， R1：1116nm， $\mathrm{R} 2: 1493 \mathrm{~nm}$ のとき NDHI の差が最大值 0.68 , 人肌と アスファルト道路では, R1：1096nm, R2：1488nm の とき NDHI の差が最大值 0.80 , また人肌と芝生などの 植生では, R1：1116nm, R2：1559nm のとき NDHI の 差が最大值 0.42 という結果が得られた。人肌に対する コンクリート壁面やアスファルト道路の NDHI の差 は大きく, 十分な抽出力がある。しかし, 人肌と芝生 などの植生では NDHIの差が比較的小さく, 抽出力も 低い。そこで，人肌と芝生などの植生で最大值をとっ た波長付近, R1：1100nm, R2：1550nmのときの人肌 とコンクリート壁面やアスファルト道路の NDHI の 差をみるとそれぞれ0.65と0.75となり，人肌との差を 十分に維持できることがわかった。よって，NDHIに

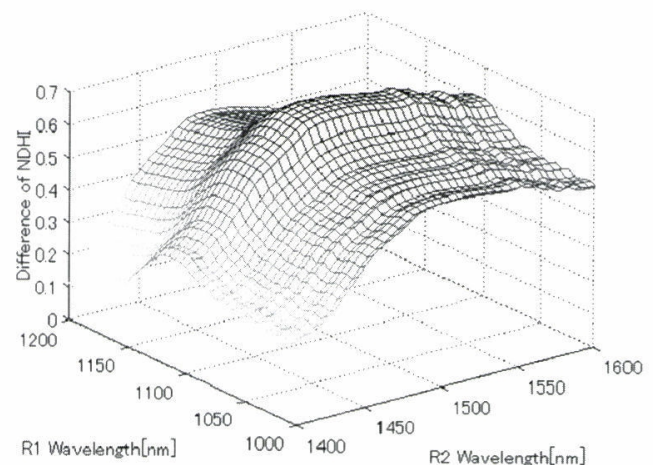

(a)

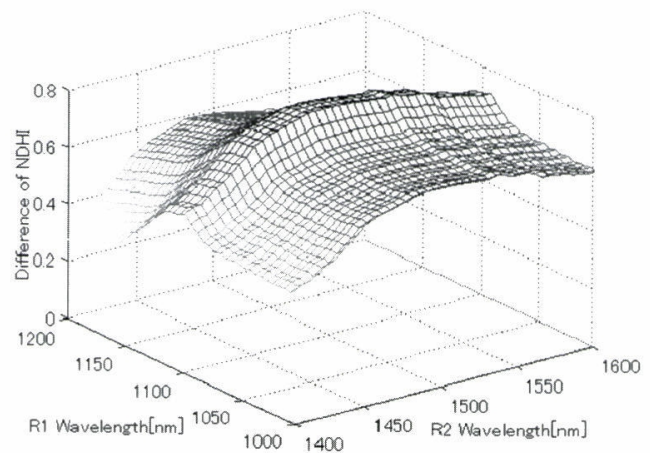

(b)

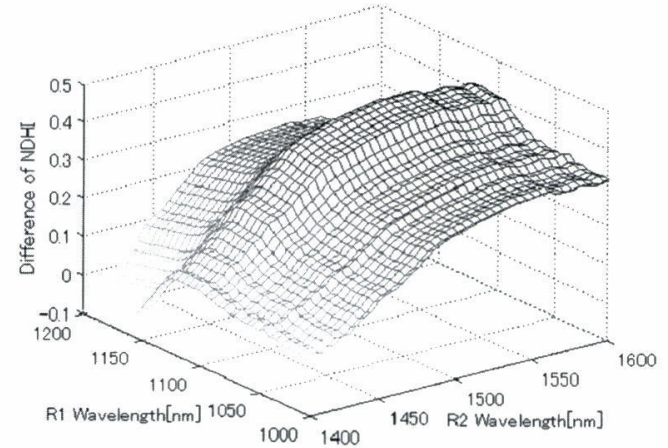

(c)

Figure 3 Difference of NDHI between human skin and various background objects. (a)Concrete wall. (b) Asphalt road. (c)Vegetation.

適切な波長を R1：1100nm, R2：1550nm とし, NDHI を次のような式とした。

$N D H I=\frac{R(1100)-R(1550)}{R(1100)+R(1550)}$

ここで， $\mathrm{R}(\lambda)$ は波長 $\lambda \mathrm{nm}$ での反射率を表してい る。 


\section{3 人肌抽出指標 NDHI の実験結果}

前節で提案した NDHI の計算式(3)を利用して, 人肌 抽出の実験及び検証を行った。実験は Figure 1 の背景 中に手を広げたヒトが立ち，計測した。個人差による NDHI の差を簡単に調べるため, モンゴロイド人種 4 名を被験者とした。NDHI を計算したものをグレース ケール化した画像（以下，NDHI 画像と呼称）を見る と, Figure 4(a)に示すように人肌の部分は高い NDHI 值を持つことがわかった。また，NDHI 值は，コンク リート壁面やアスファルト道路では小さいが, 芝生な どの植生ではやや高い值を示すことがわかった。そこ で, NDHI を閾值処理（閾值0.5）し，背景から人肌の 部分のみ抽出を行えるようにした（Figure 4 (b))。

NDHI は眉毛や頭髪を抽出していないため, ヒトと体 毛を持つ動物と区別が可能である。他の 3 名の被験者 の NDHI 画像と 2 值化画像も人肌の部分を良く抽出 できることから，モンゴロイド人種間での個人差によ るNDHIの差は少ないと考えられた (Figure 5(a)(b))。 次に，土砂域における七卜抽出の有用性を検証する ため, 土砂とヒトを含む状態で実験計測を行った。測

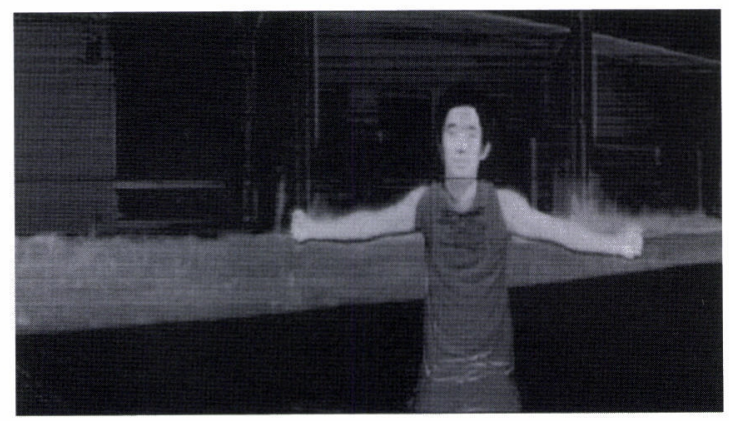

(a)

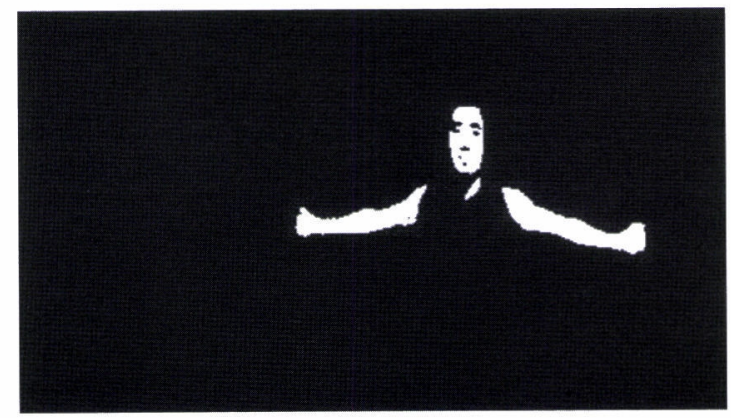

(b)

Figure 4 Calculated results of NDHI. (a)Grayscale image of NDHI. (b)Binary image of NDHI $(\mathrm{NDHI} \geqq 0.5)$.
定した背景には，土砂，ビニール製シート，建物のコ ンクリート壁面，植物などが含まれていた（Figure 6 (a))。取得されたデー夕に NDHI を適用し, NDHI 画 像と 2 值化画像を作成した（Figure 6 (b)(c))。閾值0.5 の場合，植物由来のノイズが多少みられたが，このノ イズは閾值を0.6に上げることで取り除けた。この閾值 の差の原因は, データを取得した環境の日照角度や, 測定対象物が立体構造であるため, 反射スペクトルに 対して Bidirectional Reflectance Distribution Function (BRDF) の影響が発生し (Kimes, 1983), 白色 板補正では正確に較正されない部分が存在することに よるものと考えられる。この問題はセンサから測定対 象物までの距離が離れるほど緩和され, 実際に航空機
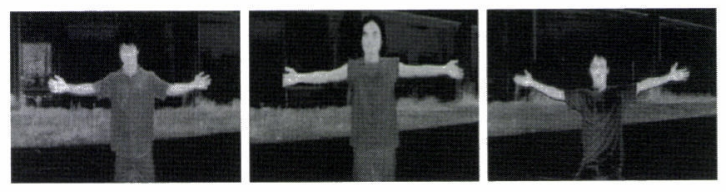

(a)
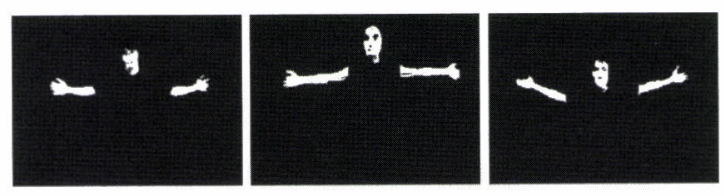

(b)

Figure 5 Calculated results of NDHI (with aspect to other three examinees). (a)Grayscale image of NDHI. (b)Binary image of NDHI (NDHIミ0.5).

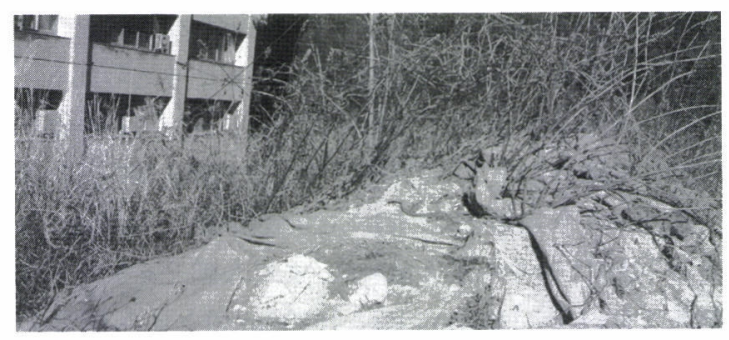

(a)

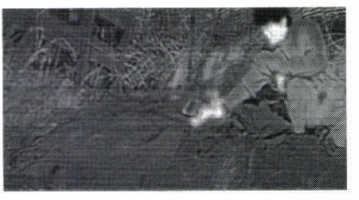

(b)

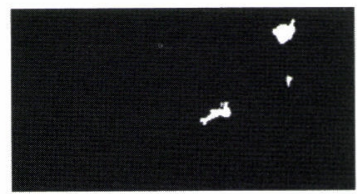

(c)
Figure 6 Calculated results of NDHI (variety of background objects including soil). (a)Background objects. (b)Grayscale image of NDHI. (c) Binary image of NDHI (NDHI $\geqq 0.6)$. 
などで上空からヒトをスキャンする場合には，誤差が 小さくなると考えられる。以上より，NDHI は土砂を 背景とした場合でも人肌抽出が可能であることが確認 された。

\section{NDHI の応用}

\section{$4.1 \mathrm{NDHI}$ を利用した要救助者の捜索}

NDHI による要救助者の捜索は, 人肌が多く露出し ている海水浴やマリンスポーツ等での水難事故や，津 波, 洪水災害後など, 上空から人肌が測定可能な状態 で広域に搜索する必要がある場面においてより有用性 を発揮すると考えられる。このような場合，実際には 水が不透明に濁っていることが多いので，NDHI を用 いて泥水内外の人肌抽出に関して検証を行った。検証 実験には室内の測定系（Figure 7 (a)）を使用した。泥 水は市販の土粘土を水に懸濁したものを使用し，透視

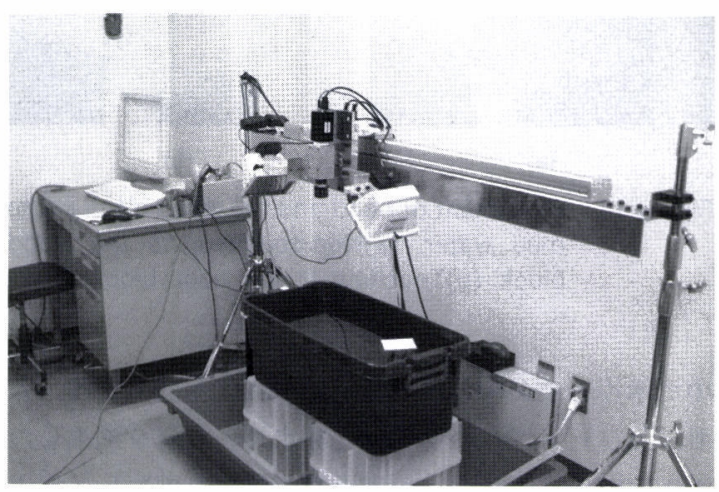

(a)

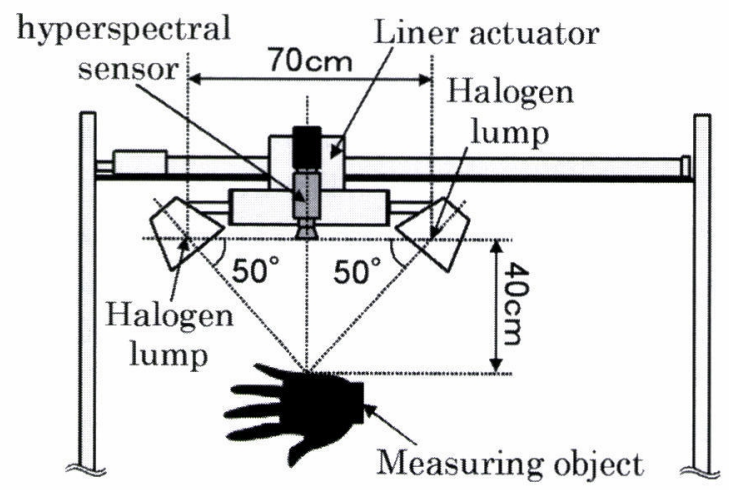

(b)

Figure 7 Measurement system in the dark room. (a) Experimental view. (b)Diagrammatic illustration.
度計を用いて濁り具合を調節した。透視度は透明なガ ラ又管に泥水を大れて徐々に排水し，上部から目視で 二重十字 (白色標識板上に太さ0.5 mm, 間隔 $1 \mathrm{~mm}$ の

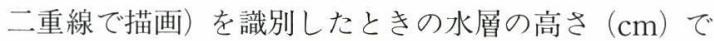
表される。また，水槽はサイズ W780 $\times$ D $390 \times$ H 370 $\mathrm{mm}$ の緑色のトランクカーゴを使用し，水面の高さを $25 \mathrm{~cm}$ とした。センサと照明, 測定対象物の位置関係は Figure 7 (b)に示す。透視度10の泥水に, 手の配置樑度 $2 \mathrm{~cm}$ で片手を浸し，測定を行った。NDHI 画像を見る と水面の NDHI 值が高く, 泥水内の人肌の確認だけで なく泥水外の人肌の認識も困難であった（Figure 8 (a)）。泥水外の人肌，泥水内の人肌及び水面のそれぞれ のスペクトルを比較すると， R(1100)において泥水内 の人肌の反射率は水面より高い值を示した（Figure 9)。また，水面の $\mathrm{R}(1550)$ の反射率がほぼ 0 に近いの で, NDHIの值が $\mathrm{R}(1100) / \mathrm{R}(1100)=1 \quad(-1 \leqq$

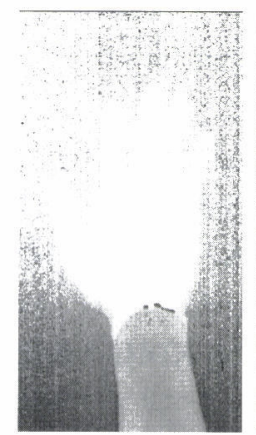

(a)

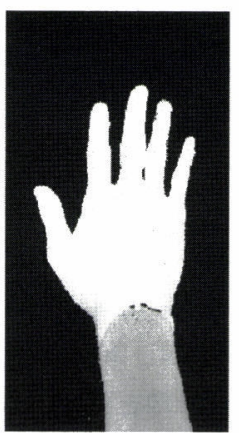

(b)

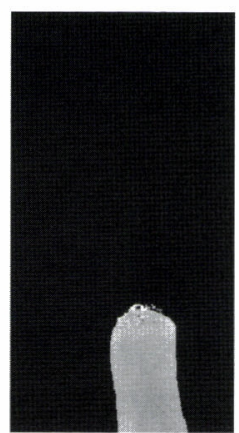

(c)
Figure $8 \mathrm{NDHI}$ of human skin and the muddy water surface. (a)Grayscale image of NDHI. (b) Grayscale image of NDHI after preprocessing $(R(1100) \geqq 0.025)$. (c) Grayscale image of $\mathrm{NDHI}$ after preprocessing $(\mathrm{R}(1100) \geqq 0.2)$.

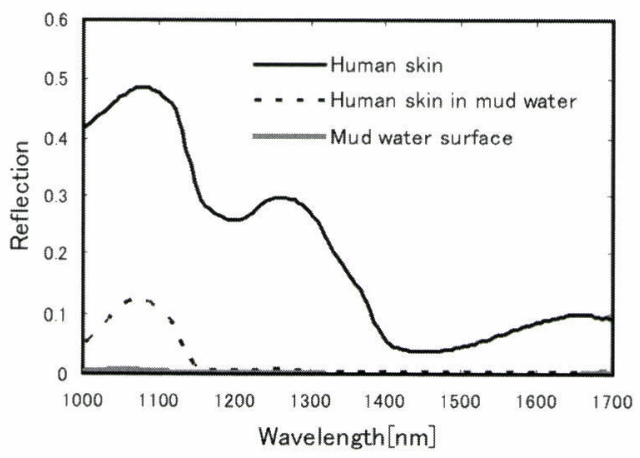

Figure 9 Hyperspectral reflectance profiles of human skin and water surface. 
$\mathrm{NDHI} \leqq 1 ） と$ 高い值になる。そこで，NDHI 算出の

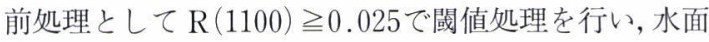
の削除を行った（Figure 8(b)）。また，閾值を $\mathrm{R}$ $(1100) \geqq 0.2$ に上げることで泥水内の人肌と水面を削 除し, 泥水外の人肌のみを抽出することが可能となっ た(Figure 8(c))。つまり，NDHI 算出の前に R(1100) の閾值処理を行うことで，泥水内の人肌と泥水外の人 肌がともに抽出可能になることがわかった。

\section{2 泥水内外のヒト識別手法}

ここまでに行ったNDHIを用いた泥水内外の七ト 識別手法出手法についてまとめる。NDHI 算出の前に $\mathrm{R}(1100)$ の閾值処理を行うことで，次の 2 枚の画像を 作成することが可能である。

(a)泥水内の物体（人肌，及び七ト以外の物体）と泥 水外の人肌を抽出した画像

(b)泥水内の物体を削除し, 泥水外の人肌のみ抽出し た画像

ただし，画像(a)，(b)の R(1100)の閾值については， 泥水内の物体の深度, 泥水の透視度ごとに調節する必 要がある。しかし，この方法ではヒ卜以外の物体が同 じ程度の水深に存在する場合，その物体を人肌と同様 に抽出するため, 泥水外の人肌と連続した泥水内の物 体を七トとして認識する必要がある。そこで，以下の 手法を提案する。画像(a)，(b)に対してを NDHI の閾值 処理を行い， 2 值化画像を作成する。ラベリング処理 として，これらの画像の連結成分にラベルを割り当て る。次に，(a)の画像から(b)の画像と重なる部分を持つ ラベルのみを抽出する。このようにして抽出された画 像(c)は，(b)の泥水外の七トと認識した部分と連結して いる水面下の物体を抽出するため, 要救助者の探索や 水面下の状況が抽出可能になると考えられる。この処 理フローを Figure 10 に示す。

そこで, 実際に NDHI を用いて上記の方法による泥 水内外の七ト識別の実験を行った。室内の測定系 (Figure 7 と同じ条件)を用い，透視度30の泥水に，手の配 置深度 $5 \mathrm{~cm}$ で片手を浸し, 測定を行った。透視度, 使 用した水槽，センサと照明，測定対象物の位置関係な どは4.1の実験と同じである。この実験においては R (1100)の閾值処理を，画像(a)では $\mathrm{R}(1100) \geqq 0.01$ ，画 像(b)では $\mathrm{R}(1100) \geqq 0.15$ とした。泥水内外の七ト識別 手法を検証するため，同深度に配置した木片と手が接 触，非接触の 2 状態で測定した（Figure $11(\mathrm{a})(\mathrm{b}))$ 。水

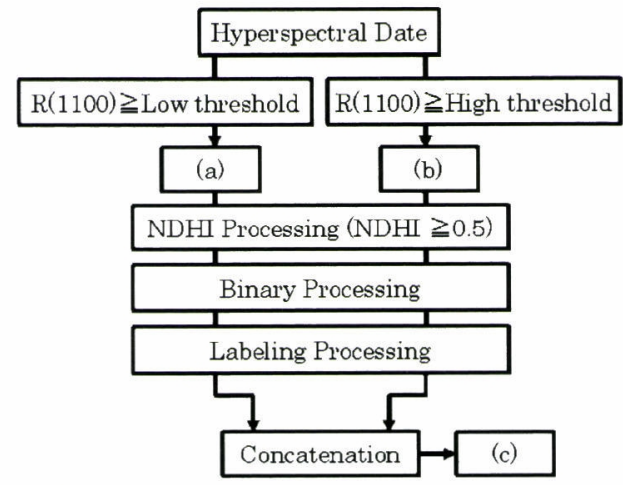

(a) Objects and human skin in and out of the mud water. (b) Human skin out of the mud water.

(c) Human parts in and out of the mud water

Regard to thresholds of R(1100), low and high thresholds depend on shin depth and mud water transparency.

Figure 10 Flow chart of the algorithm: Extracting human parts immersed in and out of the mud water.

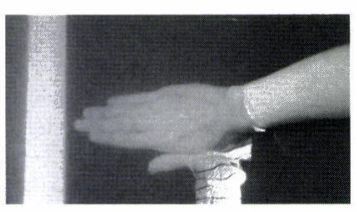

(a)

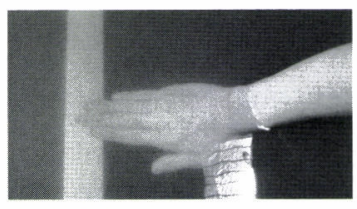

(b)
Figure 11 Placement of hand and the wood block in the mud water. (a)Non-touching to the wood block. (b)Touching to the wood block.

中で木片と手が非接触の状態での(a)泥水内の物体（人 肌，及びヒト以外の物体）と泥水外の人肌を抽出した 画像（Figure 12 (a))，(b)泥水内の物体を削除し，泥水 外の人肌のみ抽出した画像 (Figure 12 (b)), そして, その 2 枚の画像から抽出された(c)泥水外のヒトと認識 した部分と連結している水面下の物体を抽出した画像 (Figure 12 (c)) を見ると, 泥水内の七ト以外の物体を 取り除き，ヒトの部分のみを抽出できた。他方，水中 で木片と手が接触の状態での(a)(b)(c)の画像 (Figure 13 (a)(b)(c)) を見ると，泥水内でヒトに接触している物体 も抽出された。この結果より, NDHIの計算で泥水外 の人肌の抽出は可能ではあるが，泥水内の人肌のみを 抽出することは難しいことがわかった（泥水外の人肌 に連結しない泥水内の物体は削除可能)。しかし, 生存 している要救助者は身体の一部（特に呼吸のため顔面 部分) が水面から出ている可能性が高いと考之られ， 泥水外の人肌の部位を抽出することでヒトの発見は可 


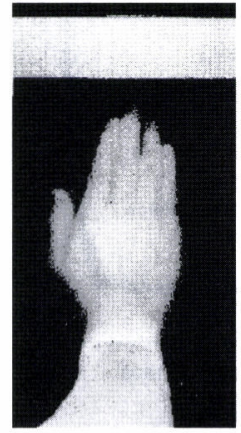

(a)

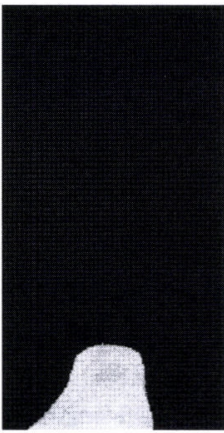

(b)

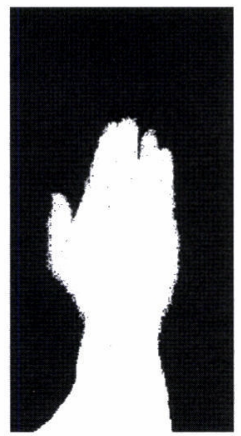

(c)
Figure 12 Method of human extraction in and out of the mud water using NDHI (Non-touching to the wood block. (a)Grayscale image of NDHI after preprocessing $(R(1100) \geqq 0.01)$. (b) Grayscale image of NDHI after preprocessing $(R(1100) \geqq 0.15)$. (c)Concatenation of binary images (a) and (b).

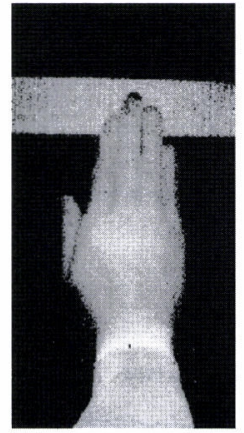

(a)

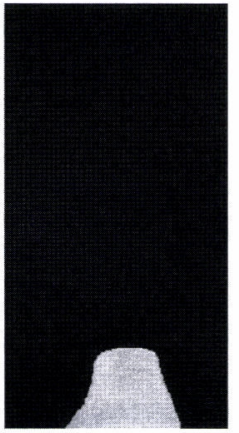

(b)

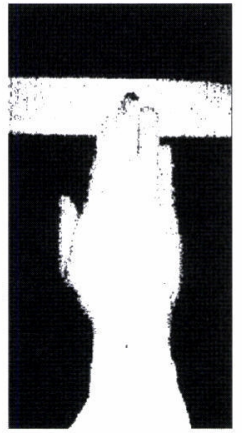

(c)
Figure 13 Method of human extraction in and out of the mud water using NDHI (Touching to the wood block. (a)Grayscale image of NDHI after preprocessing $(\mathrm{R}(1100) \geqq 0.01)$. (b) Grayscale image of NDHI after preprocessing $(R(1100) \geqq 0.15)$. (c)Concatenation of binary images (a) and (b).

能となり，連結する泥水面下の情報を得ることができ る。これは泥水外の人肌の部位だけを抽出して要救助 者を捜索するだけではなく，泥水内の情報を抽出する ことで，要救助者の状況把握にも役立つ。

\section{$4.3 \mathrm{NDHI}$ に有効な透視度と深度の関係}

泥水内の物体抽出に際し, NDHI が適用可能な泥水 の深度と透視度の関係を調査した。室内の測定系(Figure 7 と同じ条件, 但し, 水面の高さは $30 \mathrm{~cm}$ とする) を用い, 右手の甲の部分の深度が $0 \mathrm{~cm}$ から $20 \mathrm{~cm}$ に至
るまで $2 \mathrm{~cm}$ 間隔で深度を変えて測定を行った。泥水 は透視度 40,20 , 及び10の 3 種類を準備し, 透視度 $\infty$ の水として中水を用いた。それぞれの透視度における 各深度の人肌のスペクトル特性を Figure $14(\mathrm{a})$-(h)に 示した。透視度めで深度を変えた場合, 反射スペクト ルは波長1070nm 付近で反射が大きく，深度が深くな るにつれ反射が小さくなった。1150nmより長い波長 域では反射がほば 0 に近かった。そのため, NDHI を 水中の物体抽出に利用するには R1：1100nmよりも 1070nmの反射を使用卞る方が有効であると考えられ る。また, 透視度が下がると波長 $1000 \mathrm{~nm}$ から $1700 \mathrm{~nm}$ 間の反射が全体的に大きくなる傾向がみられた。これ は，透視度が下がるほど水中に含まれる土粘土の比率 が多くなり, さらに, 深度が深くなるほど土粘土の反 射影響が大きくなるためと考えられる。以上の結果か ら，次に水中の物体抽出に有効な波長 R1を $1070 \mathrm{~nm}$ に 変更し, 抽出可能な透視度と深度の関係，抽出可能な 水中の手と水面の反射率の差を調べた(Figure 15)。抽 出の可否判定は指先までの輪郭形状が日視にて認識で きるかで行っている。透視度のの場合には媣度 $10 \mathrm{~cm}$ まで, 透視度 40,20 では深度 $8 \mathrm{~cm}$ まで, 透視度 10 では 樑度 $6 \mathrm{~cm}$ まで抽出可能であった。泥水中から物体を 抽出するには，R1の閾値処理で物体のない水面を削除 する必要があり，透視度が下がると R1での水中の手と 水面の反射率の差が小さくなるため, 抽出媣度が浅く なった。各透視度での抽出可能な反射率の差を見ると， 透視度のの場合に0.0113，40では0.0142，20で0.0118， また10の場合には 0.0192 となり，10-2台で抽出の可否

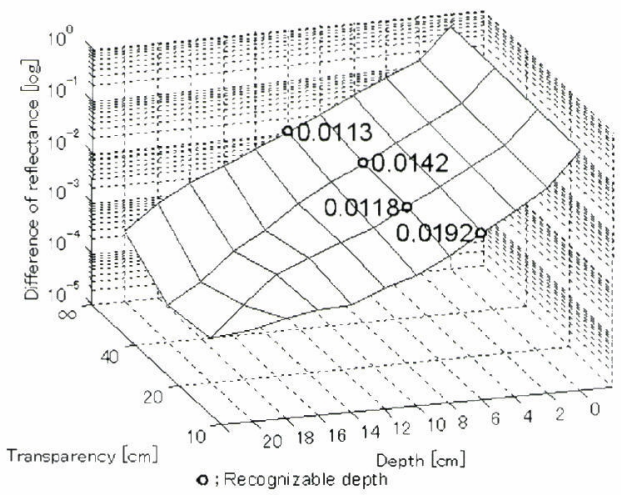

Figure 15 Difference of reflectance between human skin immersed in the mud water and water surface, and recognizable depth in each transparency. 


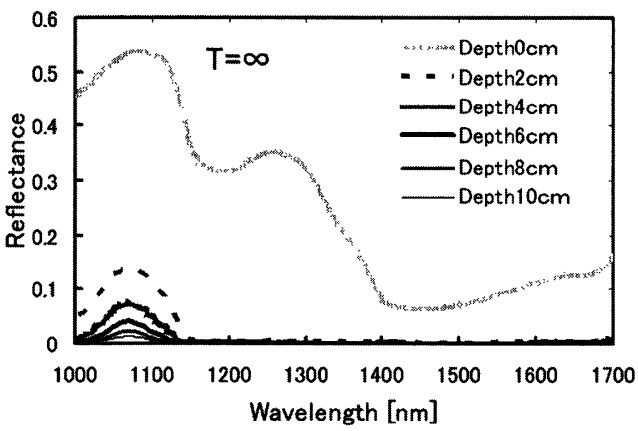

(a)

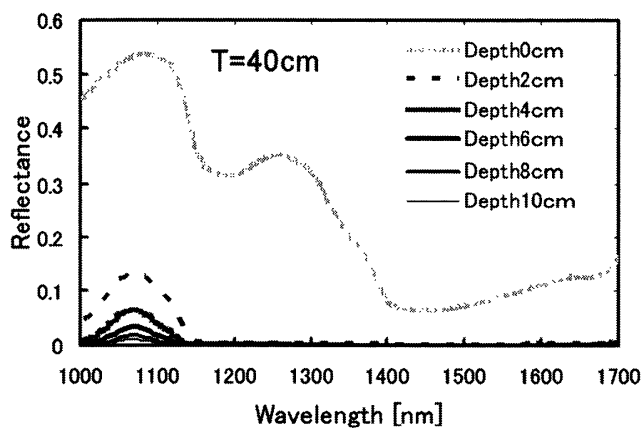

(c)

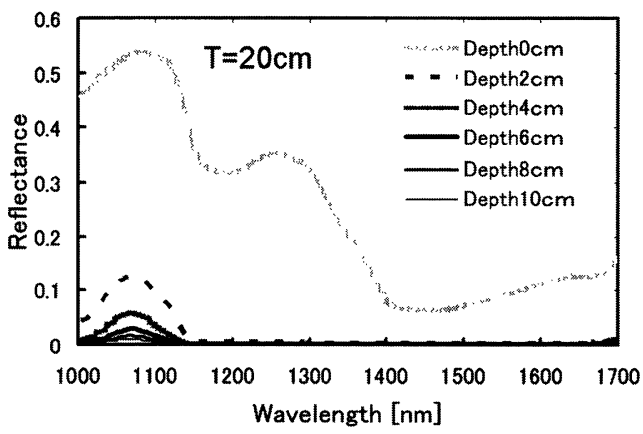

(e)

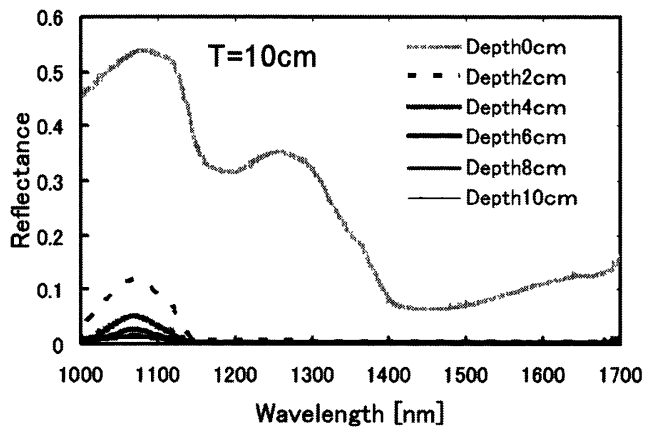

(g)

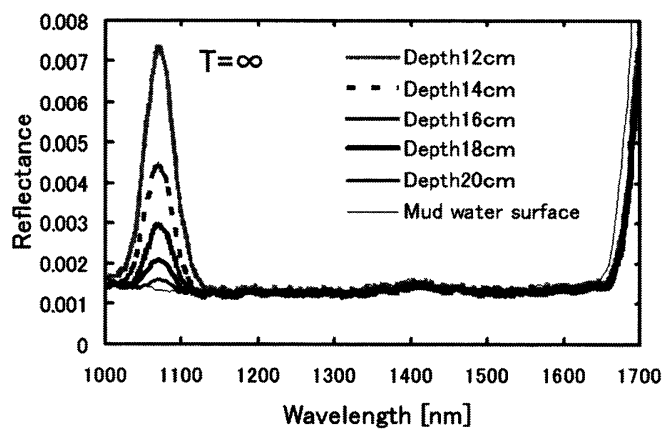

(b)

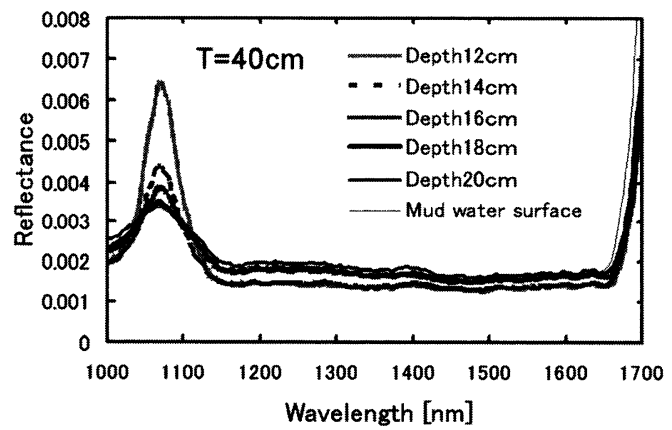

(d)

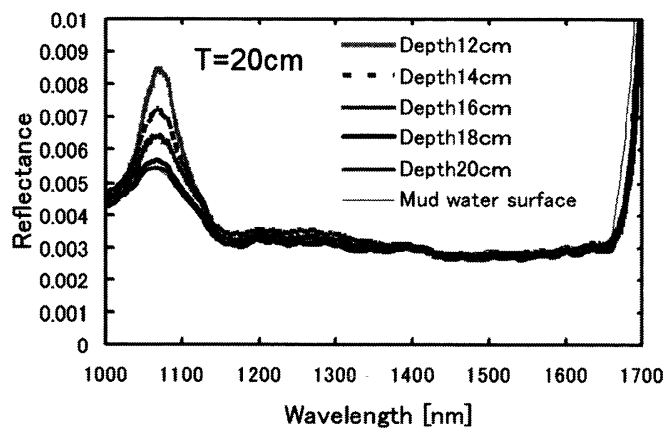

(f)

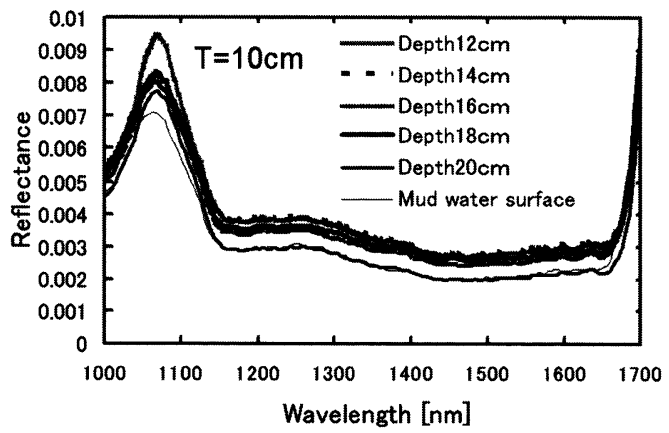

(h)

Figure 14 Hyperspectral reflectance profiles of human skin for various observation depths and transparencies. (a)(b) Pure-water ((a); depth $0-10 \mathrm{~cm},(\mathrm{~b})$; depth $12-20 \mathrm{~cm})$. (c)(d)Transparency $40 \mathrm{~cm}((\mathrm{c})$; depth $0-10 \mathrm{~cm}$, (d) ; depth $12-20 \mathrm{~cm})$. (e)(f)Transparency $20 \mathrm{~cm}((\mathrm{e})$; depth $0-10 \mathrm{~cm}$, (f) ; depth $12-20 \mathrm{~cm}) .(\mathrm{g})(\mathrm{h})$ Transparency $10 \mathrm{~cm}((\mathrm{~g})$; depth $0-10 \mathrm{~cm}$, (h); depth $12-20 \mathrm{~cm})$. 
が分かれる傾向があった。今回の実験の測定誤差とし て, 透視度 40 の深度 $16-20 \mathrm{~cm}$ 間の反射率が 0.0005 程 度上昇しており，また，透視度 10 の深度 $20 \mathrm{~cm}$ での反射 率が同程度低下した。これは暗電流值の変化による䛊 差と考えられ，対策として頻繁に暗電流值の補正を行 うか, 測定時の反射率の誤差として \pm 0.0005 程度を見 込むことが考えられる。抽出可能の判定值は $10^{-2}$ 台で あり暗電流值の䛊差に対して十分大きいため, 抽出結 果はこの誤差の影響を受けない。

\section{$4.4 \mathrm{NDHI}$ と赤外線センサを使用したヒト認識との 比較}

従来のヒト認識の主な手法の一つに熱赤外領域を利 用した赤外線センサによる体温感知がある。そこで水 難事故や水災害を想定した場面での赤外線センサによ る体温感知と NDHI との比較実験を行った。赤外線セ ンサは NEC 社製 TH3100MR を使用した。Figure 16 (a)に示すように水水中に 30 秒間右手を浸して体温を下 げた後, Figure 16 (b)に示すように透視度10の泥水中

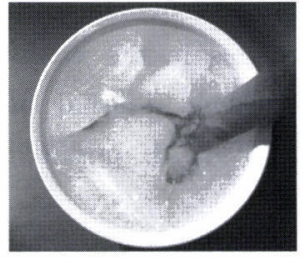

(a)

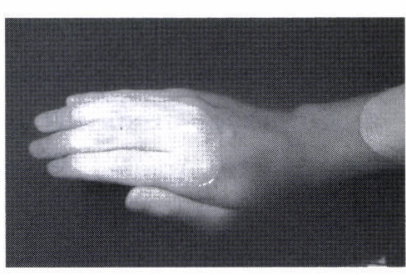

(b)
Figure 16 (a)Putting a hand for thirty seconds in the ice water. (b)View of the chilled hand in the muddy water.
に手のひらを浸し，赤外線センサと八イパースペクト ルセンサで測定を行った。海難事故や台風などによる 水災害の多発する夏期 8 月の本州周辺の海水温は 25〜29度 Cである。そこで, 泥水の温度を 25 度 Cとし た(国立天文台，2006)。赤外線センサによる測定は10 分間行い，体温が戻る様子を観察した。赤外線センサ の測定結果では, 開始直後は泥水より手のひらの体温 が低いが, 時間の経過とともに徐々に体温が戻り始め, 5 分後には泥水に接する部分の温度が27度 $\mathrm{C}$ 前後ま で回復した(Figure 17)。しかし, 水面から出ている手 の部分の温度は 10 分後も 27 度 $\mathrm{C}$ 前後から上昇せず, 手 の形状が認識できなかった。一方, NDHI 画像（R $(1100) \geqq 0.035$ で閾値処理)の結果は, 泥水内外の手の 形状が明確に抽出可能であった(Figure 18)。このよう に体温が下がっている状況での水面下のヒト認識に は，赤外線センサを使用した体温認識と比較して NDHIの方が有効であることがわかった。

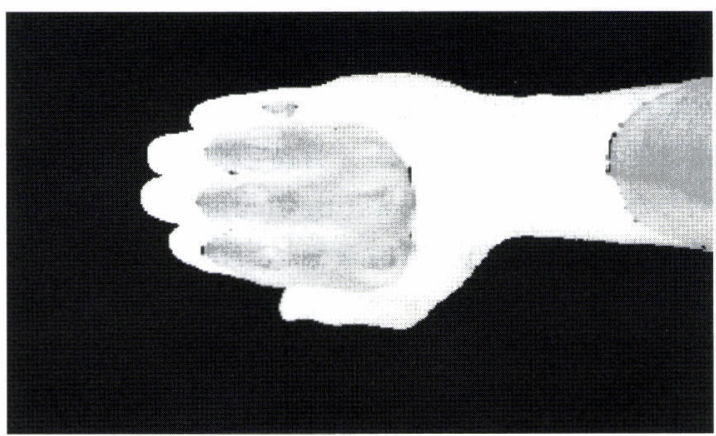

Figure 18 Calculated results of $\mathrm{NDHI}$ with respect to the chilled hand.

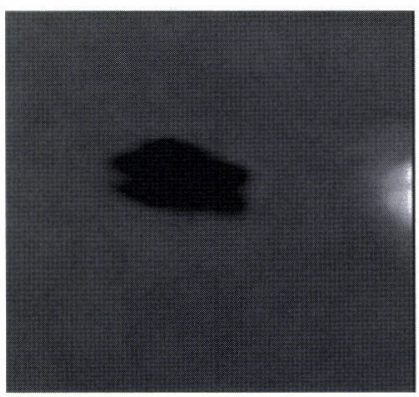

After 1 minutes.

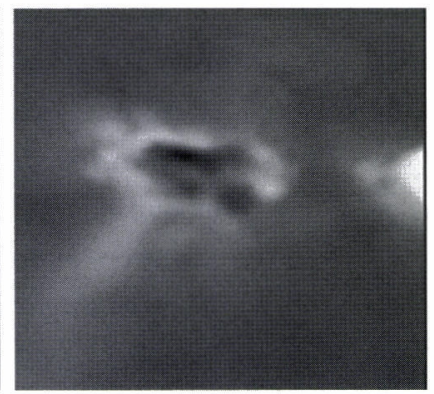

After 5 minutes.
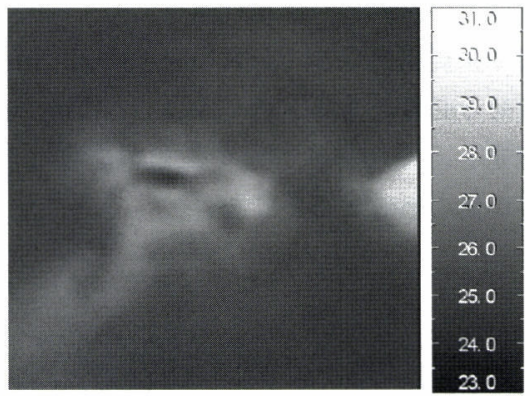

After 10 minutes.

Figure 17 Thermographical images of the chilled hand dipped in the mud water of temperature $25^{\circ} \mathrm{C}$ up to 10 minutes. 


\section{5. 結言}

ヒトと背景物の反射スペクトルの違いに基づき，背 景から人肌のみを抽出する指標 NDHI の提案を行い, その指標に最適な波長 R1：1100nm，R2：1550nm を 調査した。まず，提案したNDHIにより，ヒトをさま ざまな背景（アスファルト，コンクリート，植物，土 砂など)から識別できることを確認した。次に, NDHI による要救助者捜索に海難事故や水災害を想定し, 泥 水内外での人肌抽出の実験を行った。泥水内の物体抽 出には R1：1070nm を使用することが有効であり, 波 長1070nm の反射率を閾值処理することで取得した画 像から要救助者搜索に有効な画像の作成が可能であっ た。最後に, 従来手法の 1 つ, 赤外線センサでの体温 感知によるヒト認識との比較実験を行い，NDHIの有 用性を実証した。今後の課題として，NDHI を利用し て様々な人種の人肌をより多くの背景物及び異常気象 条件下での測定すること，実際に太陽光下で泥水内外 のヒト識別手法を検証することが必要である。そして， 泥水の透視度，測定対象物の深度によって変化する閾 值に統一的な指針を設定する必要がある。今回の実験 では泥水内外の抽出に関して目視で抽出の可否判定を 行ったが, Receiver Operating Characteristic (ROC) 法などを利用して定量的に評価し，NDHI の抽出パラ メータ(波長 $1070 \mathrm{~nm}$ の反射率の閾值 2 つ, NDHI の閾 值 1 つ）を自動最適化するなどの方法が考えられる。 また, 水中物体の短波長赤外領域の反射は対象の深度 に応じて波長 $1070 \mathrm{~nm}$ 付近に立ち上がりがあるのみで あり，暗電流值の誤差を想定すると中水中でも深度 18 $\mathrm{cm}$ 前後が抽出可能な深度の限界であることがわかっ た。しかし，目視の可視領域において純水中の物体は それ以上の深度でも認識可能なため，多領域の波長の 利用や正規指標以外の計算手法を検証し抽出精度を向 上させる必要があると考之る。さらには，夜間の救難 を想定した照明系の設定や波浪の影響などについて も，今後の検討が必要である。
謝辞

本研究は, 文部科学省大都市大震災軽減化特別プロ ジェクトの援助を受けた。赤外線センサをお貸しいた だいた秋田県立大学の浅野耕一准教授には感謝を申し 上げます。また貴重なご助言をいただいた独防災科学 技術研究所の角本繁様には厚く御礼申し上げます。

（受付日2006.10.18, 受理日2007.3.9)

\section{参考文献}

枝長孝幸，宇都有昭，小杉幸夫，2005，短波長赤外領 域スペクトル情報を用いた人肌抽出に関する研究, 日本写真測量学会平成17年度秋季学術講演会発表論 文集, pp.45-48.

枝長孝幸，宇都有昭，小杉幸夫，角本 繁，2006。 人 肌抽出指標 NDHI を用いた泥水中の人肌抽出に関 する研究，電子情報通信学会2006年度総合大会, pp. 145.

国立天文台編，2006，理科年表，pp.49-52，丸善.

A.N. Bashkatov, E.A. Genina, V.I. Kochubey, V.V. Tuchin, 2005, Optical properties of human skin, subcutaneous and mucous tissues in the wavelength range from 400 to $2000 \mathrm{~nm}$. Journal of Physics D: Applied Physics, Vol. 38, pp.25432555.

D.S. Kimes, 1983. Dynamics of directional reflectance factor distributions for vegetation canopies. Appl. Opt., 22, pp.1364-1372.

E. Angelopoulou, 1999, The Reflectance Spectrum of Human Skin, Technical Report MS-CIS-99-29, pp.1-14, http://www.cis.upenn.edu/ elli/techreport.skin.pdf.

Susan L. Ustin, 2004. Remote Sensing for Natural Resource Management and Environmental Monitoring, John Wiley \& Sons, Inc., pp.150-151. Zhihong Pan, G. Healey, M. Prasad, 2003, Face recognition in hyperspectral images. IEEE Trans. Pattern Analysis and Machine Intelligence, vol. 25, no. 12, pp.1552-1560. 